\title{
Predictors of Electrocardiographic Maladaptations in Professional Athletes in Port Harcourt, Nigeria
}

\author{
Odia, Kanayo Mercy ${ }^{1 *}$, Anugweje Kenneth Chimbuoyim ${ }^{2}$, Dapper Datonye Victor ${ }^{1}$ \\ ${ }^{1}$ Department of Human Physiology, University of Port Harcourt, Port Harcourt, Nigeria \\ ${ }^{2}$ Institute of Sports, University of Port Harcourt, Port Harcourt, Nigeria
}

DOI: $10.36348 /$ jaspe.2020.v03i03.003

| Received: 22.02.2019| Accepted: 04.03.2020 | Published: 18.03.2020

*Corresponding author: Odia, Kanayo Mercy

\section{Abstract}

Regular exercise is highly effective in cardiovascular health improvement. Professional athletes have always been regarded as exemplars of good health and have also attracted scientific curiosity on account of the strength and endurance that characterize their lifestyle. Over a period of time in athletes, cardiac adaptations to sport activities occur. The normal electrocardiographic (ECG) presentation of the heart is changed and abnormal pattern becomes present. Some of these abnormal ECG changes are suggested to be maladaptations that are risk factors for sudden cardiac death. Does the abnormal ECG pattern have anything to do with the training age of the athletes? The aim of this study is to determine the relationship between electrocardiographic abnormalities and training age of athletes in Port Harcourt, Nigeria. A cross sectional descriptive study was carried out on a total of 170 athletes consisting of 63males and 107 females (16-35years of age). Their training ages were documented and the athletes were grouped into 3: Group 1 are athletes that have been training for 1-5years; group $2: 6-10$ years and group 3 from 10 years and above. Anthropometric measurements and heart rates were determined. Physical examination was conducted to exclude the presence of associated co-morbidities. Electrocardiographic parameters were determined using a standard resting 12-lead electrocardiogram. Maladaptive ECG changes were determined using the Seattle criteria. Results showed that the training ages of athletes negatively correlated significantly with heart $\operatorname{rate}(\mathrm{R}=-0.24 ; \mathrm{P}=0.001)$ and $\mathrm{T}$-axis $(\mathrm{R}=-0.24 ; \mathrm{P}=0.01)$. Also training age positively correlated significantly with QRS- Interval $(\mathrm{R}=0.16 ; 0.03)$ and QT- Interval $(\mathrm{R}=0.22 ; 0.001)$. Athletes in group 3 (training age > 10years) recorded a significantly higher percentage of the occurrence of repolarization abnormality $\left(\square^{2}=5.50 ; \mathrm{p}=0.04\right)$. In addition, being a female and increased training age, are the significant predictors of the occurrence of a maladaptation. (Odd ratio $=4.38 ; \mathrm{p}=0.003$ and odd ratio $=1.14 ; \mathrm{p}=0.03$ respectively). The abnormal electrocardiographic changes found in this study may be due to some physiological maladaptation resulting from prolonged training age and possibly sex variation. These maladaptations are suggestive of risk factors for possible sudden cardiac death.

Keywords: Electrocardiogram, Athletes, maladaptation, training age.

Copyright @ 2020: This is an open-access article distributed under the terms of the Creative Commons Attribution license which permits unrestricted use, distribution, and reproduction in any medium for non-commercial use (NonCommercial, or CC-BY-NC) provided the original author and source are credited.

\section{INTRODUCTION}

Regular or routine exercise is highly effective in cardiovascular health improvement [1]. This has been shown in a vast number of published reports. Identified mechanisms include improvements in endothelial function and reduction of sympathetic tone, insulin sensitivity, lipid profile, blood pressure control and weight regulation [2-5]. Competitive athletes have always been regarded in all civilizations as exemplars of good health [6]. They have also attracted scientific curiosity on account of the strength and endurance that characterize their lifestyle.
Cardiac adaptations to sport activities occur over a period of time in athletes. The normal electrocardiographic (ECG) presentation of electrical activity of the heart is altered and abnormal patterns can occur over a period of time. Does the training age of an athlete have anything to do with these abnormal ECG changes? However, cardiovascular - related sudden death is the leading cause of mortality among athletes especially during sports [7].

A situation where the icons of health and fitness (athletes) become victims of sudden cardiac death [8], requires proper investigations in order to draw a clear cut line on the limit to which the effect of 
exercise on the heart becomes a pointer to a potential risk factor of sudden cardiac death.

The aim of this study therefore is to determine the relationship between Electrocardiograph parameters and the training age of athletes in Port Harcourt.

The training age of an athlete is regarded as the number of years that athlete has been in a properly structured training program.

\section{MATERIALS AND METHODS}

A cross sectional descriptive study was carried out on a total of 170 athletes consisting of 63 males and 107 females. All subjects were grouped into 5 categories of Sports: agility, endurance, power, speed and strength, according to their predominant biomotor ability [9]. All subjects were aged between 16 and $35 y e a r s$. Anthropometric measurements and heart rates were determined. Physical examination was conducted to exclude the presence of associated co-morbidities. Electrocardiographic parameters were determined using a standard resting 12-lead electrocardiogram. The electrocardiogram was done on each subject, according to the recommendations of the American Heart Association and the American College of Cardiology. [10].

A Schiller AT - 2plus model standard resting twelve (12) - lead electrocardiographic machine with a paper speed of $25 \mathrm{~mm} / \mathrm{sec}$ and standardized at $0.1 \mathrm{mv} / \mathrm{mm}$ was used. A non- irritant electrode gel, Standard BP apparatus, reclining bed and power source were used. Maladaptive ECG changes were determined using the Seattle criteria [11].

\section{Subjects and Condition}

Subjects that have lived and have had at least one year of regular training experience in Nigeria, were included in this study. Subjects that have history and clinical features of heart disease, hypertension and/or diabetes were excluded from the study. Subjects who had electrolyte disturbances and those on fluid therapy (e.g recent blood transfusion within 3 months) were also excluded. Also subjects on anabolic steroids or alcohol consumption of more than 8 pints of beer or more than 1 pint of spirit daily were excluded. Subjects that are current smokers (smoking presently or smoking within the 2years preceding this study as defined by Centers for Disease Control and Prevention, 1992) [12]; were also excluded. Subjects that are sick especially with fever and subjects that are on ionotropic agents eg Digoxin were excluded from the study.

\section{Sample Size Estimation}

The minimum sample size of subjects required for this study was determined using Morris' formula for small (hyper-geometric) population [13].

\section{Medical and Experimental Ethics}

Ethical approval was obtained from the Ethics Committee of the University of Port Harcourt. The objective and nature of the study was explained to the subjects before enlistment. Informed consent was sought from the participants and the Rivers State Sports Council before the study.

\section{STATISTICAL ANALYSIS}

Analysis was made using SPSS version 21.0 statistical package. The Z- test was used to compare continuous variables while Pearson's correlation was used to establish association between categorical variables. Logistic Regression was used to predict the occurrence of maladaptation. Variance was set at infinity and a P- value less than 0.05 was considered significant.

\section{RESULTS AND DISCUSSION}

Table-1 shows the distribution of participants across various categories of sports. For the category of agility sports, the participants made up $14.1 \%$ (15.9\% males and females $13.1 \%$ ) of all other sports considered in this study. Endurance sport participants made up $15.3 \%$ (male $7.9 \%$ and female $19.7 \%$ ) of the entire participants. Participants in power sports category made up $28.8 \%$ (34.9\% for male and $25.2 \%$ for females) of the study sample. On speed category of sport, the participants made up 28.2\% (male $28.6 \%$ and female 28.8) of the study subject. And finally, on strength category of sport, the participants made up $11.8 \%$ ( $11.1 \%$ male; $12.1 \%$ female) of our sampled subjects.

Table- 2 represents the data on the training age of the sampled athletes. The training ages of the study participants were categorized into three 1 to 5years; 6 to 10years and above 10years. Out of the 170 athletes that participated in the current study, $43.5 \%$ (52.4\% males and $38.3 \%$ females) has only trained between 1 and 5years. The participants that have trained between 6 and 10years made up $40 \%$ (38.1 males and $41.1 \%$ females) of the study participants. Lastly, only $16.5 \% \quad(9.5 \%$ males and $20.6 \%$ females) of the study subjects had trained for above 10years.

The result on Table-3 shows the relationship between electrocardiographic (ECG) parameters and period of training. It was observed in this study that, training age of the athletes significantly $(\mathrm{P}=0.001)$ and negatively correlated with heart rate $(\mathrm{R}=-0.24)$. Similarly, training age significantly and negatively correlated with $\mathrm{T}$-axis changes $(\mathrm{P}=0.01 ; \mathrm{R}=-0.24)$.

On the other hand, a significant and positive correlations were recorded for both training age and QT-interval $(\mathrm{P}=0.001 ; \mathrm{R}=-0.22)$ and training age and $\mathrm{QRS}$-interval $(\mathrm{P}=0.03 ; \mathrm{R}=0.16)$.

Tables-4 A and B show the prevalence of maladaptive ECG features in athletes compared by 
training age. The $\%$ of athlete with repolarization abnormality was found to be significantly higher in group 3 (training age $>10$ years; $\mathrm{P}=0.04$ ).

In Table-5, the result of the prediction of occurrence of maladaptive ECG features using regression model is shown. It was observed that the female gender and increasing training age are significant predicators of the occurrence of maladaptive
ECG features (Odd ratio $=4.05, p<0.003 ;$ odd ratio $=$ $1.10, P<0.03$ respectively) athletes. More so, in the adjusted regression model. The outcome of the adjusted regression model predicted that female's athletes are 4.38 times more likely to present with ECG maladaptation compared to their male counterparts. It was also found that BMI, age and sports category did not significantly $(\mathrm{P}>0.05)$ predict the occurrence of maladaptation.

Table-1: Distribution of Participants across Various Categories of Sport

\begin{tabular}{|c|c|c|c|}
\hline Category of Sport & $\begin{array}{l}\text { Frequency } \\
\text { (n) }\end{array}$ & & \\
\hline & Male (\%) & $\begin{array}{l}\text { Female } \\
(\%)\end{array}$ & $\begin{array}{l}\text { Total } \\
(\%)\end{array}$ \\
\hline Agility [Tennis, badminton, squash] & $10(15.9)$ & $15(13.1)$ & $25(14.1)$ \\
\hline 2. Endurance [marathon/long distance run, endurance swimming] & $5(7.9)$ & $21(19.7)$ & $26(15.3)$ \\
\hline 3. Power [wrestling, judo, taekwondo, rugby] & $22(34.9)$ & $27(25.2)$ & $49(28.8)$ \\
\hline 4. Speed [sprints swimming $(100 \mathrm{~m}, 200 \mathrm{~m})$ & $19(28.6)$ & $31(28.0)$ & $50(28.2)$ \\
\hline $\begin{array}{l}\text { 5. Strength [weight lifting, shot put, discus, javelin, jumps and } \\
\text { hurdle] }\end{array}$ & $7(11.1)$ & $13(12.1)$ & $20(11.8)$ \\
\hline Total & 63 & 107 & 170 \\
\hline
\end{tabular}

Table-2: Training age of athletes

\begin{tabular}{|l|l|l|l|}
\hline Training age & $\begin{array}{l}\text { Frequency } \\
\mathrm{n}(\%)\end{array}$ & $\begin{array}{l}\text { Male } \\
\mathrm{n}(\%)\end{array}$ & $\begin{array}{l}\text { female } \\
\mathrm{n}(\%)\end{array}$ \\
\hline $1-5$ years & $74(43.5)$ & $33(52.4)$ & $41(38.3)$ \\
\hline $6-10$ years & $68(40)$ & $24(38.1)$ & $44(41.1)$ \\
\hline$>10$ years & $28(16.5)$ & $6(9.5)$ & $22(20.6)$ \\
\hline Total & $170(100)$ & 63 & 107 \\
\hline $\begin{array}{l}\text { Mean years in training } \\
\text { (mean } \pm \text { SD) in years }\end{array}$ & $\mathbf{7 . 2 7} \pm \mathbf{4 . 1 0}$ & $\mathbf{6 . 2 9} \pm \mathbf{3 . 3 5}$ & $\mathbf{7 . 8 5} \pm \mathbf{4 . 4 0}$ \\
\hline
\end{tabular}

Table-3: Relationship between Electrocardiographic parameters and Period of training

\begin{tabular}{|c|c|c|}
\hline ECG PARAMETERS & & TRAINING AGE (IN YEARS) \\
\hline & $\mathrm{R}$ & P-value \\
\hline Heart Rate (bpm) & -0.24 & $0.001 *$ \\
\hline P-axis $\left(^{0}\right)$ & 0.10 & 0.20 \\
\hline QRS-axis ( ${ }^{\mathbf{0}}$ ) & -0.10 & 0.20 \\
\hline T-axis( $\left(^{0}\right)$ & -0.24 & 0.001* \\
\hline PR-Interval (ms) & -0.11 & 0.17 \\
\hline QRS-Interval(ms) & 0.16 & 0.03* \\
\hline QT-Interval (ms) & 0.22 & 0.001* \\
\hline $\mathbf{Q T}_{\mathrm{c}}$-Interval (ms) & -0.13 & 0.10 \\
\hline
\end{tabular}

Table-4A: Maladaptive ECG features in athletes compared by training age

\begin{tabular}{|l|l|l|l|l|}
\hline \multirow{2}{*}{ ECG features } & \multicolumn{3}{|c|}{ Training age } & \multirow{2}{*}{ Chi-square(p-value) } \\
\cline { 2 - 4 } & $\mathbf{1 - 5}$ years & $\mathbf{6 - 1 0 y e a r s}$ & Above 10 years & \\
\hline $\begin{array}{l}\text { Lat.subepicardial injury } \\
\text { No }\end{array}$ & $74(100.0)$ & $67(98.5)$ & $28(100.0)$ & \multirow{2}{*}{$1.51(0.57)$} \\
\hline Yes & $0(0.0)$ & $1(1.5)$ & $0(0.0)$ & \\
\hline $\begin{array}{l}\text { Pericarditis } \\
\text { No }\end{array}$ & $74(100.0)$ & $67(98.5)$ & $28(100.0)$ & $1.51(0.57)$ \\
\hline Yes & $0(0.0)$ & $1(1.5)$ & $0(0.0)$ & \\
\hline $\begin{array}{l}\text { Pathological Q-wave } \\
\text { No }\end{array}$ & $73(98.6)$ & $68(100.0)$ & $28(100.0)$ & $1.31(1.00)$ \\
\hline Yes & $1(1.4)$ & $0(0.0)$ & $0(0.0)$ & \\
\hline Left axis deviation & & & & \\
\hline
\end{tabular}




\begin{tabular}{|l|l|l|l|l|}
\hline No & $71(95.9)$ & $63(92.6)$ & $26(92.9)$ & $0.79(0.68)$ \\
\hline Yes & $3(4.1)$ & $5(7.4)$ & $2(7.1)$ & \\
\hline $\begin{array}{l}\text { Complete LBBB } \\
\text { No }\end{array}$ & $73(98.6)$ & $68(100.0)$ & $28(100.0)$ & $1.31(1.00)$ \\
\hline Yes & $1(1.4)$ & $0(0.0)$ & $0(0.0)$ & \\
\hline $\begin{array}{l}\text { Ischeamia } \\
\text { No }\end{array}$ & $74(100.0)$ & $66(97.1)$ & $28(100.0)$ & $3.04(0.19)$ \\
\hline Yes & $0(0.0)$ & $2(2.9)$ & $0(0.0)$ & \\
\hline
\end{tabular}

Table-4B: Mal adaptive ECG features in athletes compared by training age (contd)

\begin{tabular}{|l|l|l|l|l|}
\hline \multirow{2}{*}{ ECG features } & \multicolumn{3}{|c|}{ Training age } & Chi-square(p-value) \\
\cline { 2 - 4 } $\begin{array}{l}\text { Short QT- interval } \\
\text { No }\end{array}$ & $\mathbf{1 - 5}$ years & $\mathbf{6 - 1 0 y e a r s}$ & Above 10 years & \\
\hline Yes & $73(98.6)$ & $67(98.5)$ & $28(100.0)$ & $4.03(1.00)$ \\
\hline $\begin{array}{l}\text { Repolarization abnormality } \\
\text { No }\end{array}$ & $1(1.4)$ & $1(1.5)$ & $0(0.0)$ & \\
\hline Yes & $71(95.9)$ & $66(97.1)$ & $24(85.7)$ & $\mathbf{5 . 5 0 ( 0 . 0 4 ) *}$ \\
\hline $\begin{array}{l}\text { Abnormal LVH } \\
\text { No }\end{array}$ & $3(4.1)$ & $2(2.9)$ & $4(14.3)$ & \\
\hline Yes & $66(90.4)$ & $64(94.1)$ & $27(96.4)$ & $1.37(0.57)$ \\
\hline $\begin{array}{l}\text { Right ventricular hypertrophy } \\
\text { No }\end{array}$ & $7(9.6)$ & $4(5.9)$ & $1(3.6)$ & \\
\hline Yes & $73(98.6)$ & $68(100.0)$ & $28(100.0)$ & $1.31(1.00)$ \\
\hline $\begin{array}{l}\text { left atrial hypertrophy(Pmitrale) } \\
\text { No }\end{array}$ & $1(1.4)$ & $0(0.0)$ & $0(0.0)$ & \\
\hline Yes & $71(95.9)$ & $67(98.5)$ & $26(92.9)$ & $1.98(0.40)$ \\
\hline $\begin{array}{l}\text { ST-T elevation abnormality } \\
\text { No }\end{array}$ & $3(4.1)$ & $1(1.5)$ & $2(7.1)$ & $1.53(0.54)$ \\
\hline Yes & $70(94.6)$ & $65(95.6)$ & $28(100.0)$ & \\
\hline
\end{tabular}

Table-5: Regression model predicting the occurrence of maladaptive ECG features

\begin{tabular}{|l|l|l|l|l|}
\hline Variables & $\begin{array}{l}\text { Crude odds Ratio } \\
\text { (95\% confidence interval) }\end{array}$ & $\begin{array}{l}\text { P- } \\
\text { Value }\end{array}$ & $\begin{array}{l}\text { Adjusted odds Ratio (95\% } \\
\text { confidence interval) }\end{array}$ & $\begin{array}{l}\text { P- } \\
\text { Value }\end{array}$ \\
\hline $\begin{array}{l}\text { Sex } \\
\text { Females } \\
\text { Males(Ref) }\end{array}$ & $4.05(1.59-10.5)$ & 0.003 & $4.38(1.65-11.64)$ & $\mathbf{0 . 0 0 3}^{*}$ \\
\hline Age(years) & $1.02(0.93-1.10)$ & 0.74 & $0.94(0.83-1.05)$ & 0.28 \\
\hline BMI & $0.98(0.87-1.10)$ & 0.67 & $0.94(0.81-1.09)$ & 0.41 \\
\hline Training age (years) & $1.10(1.01-1.20)$ & 0.03 & $1.14(1.01-1.28)$ & $\mathbf{0 . 0 3 *}$ \\
\hline $\begin{array}{l}\text { Sports Type } \\
\text { Agility/Speed/Flexibility } \\
\text { Vs Endurance/power/strength (ref) }\end{array}$ & $0.56(0.27-1.16)$ & 0.12 & $0.61(0.27-1.39)$ & 0.24 \\
\hline
\end{tabular}

\section{DISCUSSION}

Participation in different sports is known to promote good health [14]. Importantly, proper and correct electrocardiographic screening in preparticipation in different sports, especially in athletics, can save athletes' lives as well as improve their social and economic benefits [15]. Resultantly, the present study in its evaluation of the relationship between electrocardiographic abnormalities and training age of athletes in Port Harcourt, Nigeria, investigated participants drawn from various categories of sports including agility, endurance, power, speed and strength sports and some interesting findings were made.
The present study found that, out of the 170 athletes that were screened, $43.5 \%$ (52.4\% males and $38.3 \%$ females) had only trained between I and 5years; while $40 \%$ (38.1 males and $41.1 \%$ females) had trained between 6 and 10years and lastly, only $16.5 \%(9.5 \%$ males and $20.6 \%$ females) of these had trained for above 10years. This outcome has validated the earlier report of Eime et al., [14] who explained that, major participation in various sports is common amongst young people and it has been reported that participation declines with age. This finding is consistent with already established facts, as physiologic adaptive homeostasis capacity is known to decline with severe physical and environmental conditions as well as ageing [16]; thus the need to promote ECG screening of 
athletes for recognizing silent cardiovascular disease [17-19].

The present study also recorded that, training age of the athletes significantly and negatively correlated with heart rate. This implies a slower heart rate with increasing training age. Bradycardia is as a result of physiological adaptation amongst our athletes. This bradycardia serves to ensure a more efficient heart with a larger stroke volume with fewer cardiac contractions during each cardiac cycle[20]. Further, impaired cardiac autonomic function, assessed noninvasively by spontaneous heart rate variability using the ECG, is associated with an elevated chance of sudden death after myocardial infarction [21, 22]. This study found that the longer the training age of an athlete, the more the individual becomes more predisposed to training-induced maladaptation (like Repolarization abnormality and abnormal LVH) with their attendant morbidity and possible mortality.

This study also found that training age significantly and negatively correlated with $\mathrm{T}$-axis changes. [23] earlier noted that $\mathrm{T}$-wave axis shift may represent a general marker of ventricular repolarization abnormalities and a possible indicator of raised chances of cardiovascular mortality. This observation buttresses the previous finding of the present study on the significant relationship between training ages of the athletes with their heart rates.

Finally, this study observed that the female gender and increasing training age are significant predicators of the occurrence of maladaptive ECG features in the female subjects. This finding fulfills the earlier request of Colombo and Finocchiaro [24], who considering the increasing participation of women in sports advocated for more female gender based investigations as to improve the understanding of cardiac adaptation to exercise in female athletes. This finding elucidates earlier findings which mention that females are more likely to suffer cardiac failure especially following infarction or severe demands placed by strenuous physical activities $[25,26]$.

In conclusion, electrocardiographic mal adaptation in Nigerian athletes possibly has gender bias. Also, the longer the training age in years, the higher the chances of developing a maladaptation that points to sudden cardiac death. While there is an increasing participation in peak sports like athletics recently, there is need for regular pre-participation ECG screening by sports organisations as this will help save athletes' lives as well as improve their social and economic value. This will also help in predicting the appropriate retirement age for athlete.

\section{REFERENCES}

1. Stampfer, M. J., Hu, F. B., Manson, J. E., Rimm, E. B., \& Willett, W. C. (2000). Primary prevention of coronary heart disease in women through diet and lifestyle. New England Journal of Medicine, 343(1), 16-22.

2. Adamu, B., Sani, M. U., \& Abdu, A. (2006). Physical exercise and health: a review. Nigerian journal of medicine: journal of the National Association of Resident Doctors of Nigeria, 15(3), 190-196.

3. Boraita Pérez, A. (2008). Exercise as the cornerstone of cardiovascular prevention. Revista Espanola de Cardiologİa (English Edition), 61(5), 514-528.

4. Byberg, L., Zethelius, B., McKeigue, P. M., \& Lithell, H. O. (2001). Changes in physical activity are associated with changes in metabolic cardiovascular risk factors. Diabetologia, 44(12), 2134-2139.

5. Shiroma, E. J., \& Lee, I. M. (2010). Physical activity and cardiovascular health: lessons learned from epidemiological studies across age, gender, and race/ethnicity. Circulation, 122(7), 743-752.

6. Battle, R. W., Mistry, D. J., Malhotra, R., MacKnight, J. M., Saliba, E. N., \& Mahapatra, S. (2011). Cardiovascular screening and the elite athlete: advances, concepts, controversies, and a view of the future. Clinics in sports medicine, 30(3), 503-524.

7. Harmon, K. G., Drezner, J. A., Klossner, D., \& Asif, I. M. (2012). Sickle cell trait associated with a RR of death of 37 times in National Collegiate Athletic Association football athletes: a database with 2 million athlete-years as the denominator. British Journal of Sports Medicine, 46(5), 325-330.

8. Lawan, A., Ali, M. A., \& Bauchi, S. D. (2008). Evaluation of 12-lead electrocardiogram (ECG) in athletes and non-athletes in Zaria, Nigeria. Pakistan journal of Physiology, 4(1), $27-$ 29.

9. Marchant, M. (2013). The 8 Abilities of an Athlete - Blog/Marchant Method. Available online at: http://www.marchantmethod.com/articles/commen ts/the-8-abilities-of-an-athlete

10. Kligfield, P., Gettes, L. S., Bailey, J. J., Childers, R., Deal, B. J., Hancock, E. W., ... \& Pahlm, O. (2007). Recommendations for the standardization and interpretation of the electrocardiogram: part I: the electrocardiogram and its technology a scientific statement from the American Heart Association Electrocardiography and Arrhythmias Committee, Council on Clinical Cardiology; the American College of Cardiology Foundation; and the Heart Rhythm Society endorsed by the International Society for Computerized Electrocardiology. Journal of the American College of Cardiology, 49(10), 1109-1127.

11. Drezner, J. A., Ackerman, M. J., Anderson, J., Ashley, E., Asplund, C. A., Baggish, A. L., ... \& 
Fischbach, P. (2013). Electrocardiographic interpretation in athletes: the 'Seattle criteria'. $\mathrm{Br} \mathrm{J}$ Sports Med, 47(3), 122-124.

12. Centers for Disease Control and Prevention (CDC. (1994). Cigarette smoking among adults--United States, 1992, and changes in the definition of current cigarette smoking. MMWR. Morbidity and mortality weekly report, 43(19), 342-346.

13. Morris, E. (2014). Believing is seeing: Observations on the mysteries of photography. Penguin.

14. Eime, R. M., Harvey, J. T., Charity, M. J., Casey, M. M., Westerbeek, H., \& Payne, W. R. (2016). Age profiles of sport participants. BMC sports science, medicine and rehabilitation, 8(1):1-10.

15. Corrado, D., \& McKenna, W. J. (2007). Appropriate interpretation of the athlete's electrocardiogram saves lives as well as money. Eur Heart Journal, 28:1920-1922.

16. Pomatto, L. C., Sun, P. Y., \& Davies, K. J. (2019). To adapt or not to adapt: Consequences of declining Adaptive Homeostasis and Proteostasis with age. Mechanisms of ageing and development, 177, 80-87.

17. Wellens, H. J., \& Gorgels, A. P. (2011). How important is the electrocardiogram in protecting and guiding the athlete?. Circulation, 124:669671.

18. Uberoi, A., Stein, R., Perez, M. V., Freeman, J., Wheeler, M., Dewey, F., ... \& Pelliccia, A. (2011). Interpretation of the electrocardiogram of young athletes. Circulation, 124(6), 746-757.

19. Malhotra, R., West, J. J., Dent, J., Luna, M., Kramer, C. M., Mounsey, J. P., ... \& MacKnight,
J. (2011). Cost and yield of adding electrocardiography to history and physical in screening Division I intercollegiate athletes: a 5year experience. Heart Rhythm, 8(5), 721-727.

20. Maron, B. J., \& Pelliccia, A. (2006). The heart of trained athletes: cardiac remodeling and the risks of sports, including sudden death. Circulation, 114(15), 1633-1644.

21. Mandawat, M. K., Wallbridge, D. R., Pringle, S. D., Riyami, A. A., Latif, S., Macfarlane, P. W., ... \& Cobbe, S. M. (1995). Heart rate variability in left ventricular hypertrophy. Heart, 73(2), 139144.

22. Lombardi, F. (2011). Origin of heart rate variability and turbulence: an appraisal of autonomic modulation of cardiovascular function. Frontiers in Physiology, 2, 95.

23. Salles, G. F., Xavier, S. S., Sousa, A. S., Hasslocher-Moreno, A., \& Cardoso, C. R. (2004). $\mathrm{T}$-wave axis deviation as an independent predictor of mortality in chronic Chagas' disease. The American journal of cardiology, 93(9), 1136-1140.

24. Colombo, C. S. S., \& Finocchiaro, G. (2018). The female athlete's heart: facts and fallacies. Current treatment options in cardiovascular medicine, 20(12):101.

25. Hayward, C. S., Kalnins, W. V., \& Kelly, R. P. (2001). Gender-related differences in left ventricular chamber function. Cardiovascular research, 49(2), 340-350.

26. Bessem, B., de Bruijn, M. C., \& Nieuwland, W. (2017). Gender differences in the electrocardiogram screening of athletes. Journal of science and medicine in sport, 20(2), 213-217. 